\title{
Phylogenetic analyses of eight isolates of Phakopsora meibomiae collected in Puerto Rico ${ }^{1,2}$
}

\author{
Byron Vega ${ }^{3}$ and Consuelo Estévez de Jensen ${ }^{4}$
}

J. Agric. Univ. PR. 95(1-2):45-55 (2011)

\begin{abstract}
American soybean rust (AmSR) caused by Phakopsora meibomiae (Arthur) Arthur is limited to certain areas of the Western Hemisphere. It is not known to cause severe losses to economically important crops. Phakopsora meibomiae naturally infects 42 species of legumes of the subfamily Papilionoidea. During 2008, eight isolates of AmSR infecting Lablab purpureus were collected in the central mountainous area of Puerto Rico. Molecular phylogenetic analyses of the internal transcribed spacer (ITS) region, including 5.85 ribosomal DNA (rDNA), were conducted. The topology of the trees generated by parsimony and by Neighbor-Joining methods was similar. Isolates were identified as Phakopsora meibomiae, with 98 and $100 \%$ identity. These isolates formed a monophyletic group. Asian Soybean Rust, Phakopsora pachyrhizi, the most closely related species, formed a second clade. Other rust species of the genera Uromyces, Puccinia, Tranzschelia, Hemileia, Ustilago smut, and the edible mushroom Boletus were included in the analyses as outgroups. Phakopsora species grouped in the Pucciniaceae family formed a sister clade to Phakopsoraceae and Uropyxidaceae families.
\end{abstract}

Key words: American soybean rust, phylogenetic analyses

\section{RESUMEN}

Análisis filogenético de la roya americana de la soya, Phakopsora meibomiae

La roya americana de la soya (AmSR), causada por Phakopsora meibomiae (Arthur) Arthur, se encuentra limitada a pocas áreas del Hemisferio Occidental. No se conocen pérdidas severas causadas por este patógeno en cultivos de importancia económica. Phakopsora meibomiae infecta naturalmente 42 especies de leguminosas de la subfamilia Papilionoidea. Durante el 2008, se colectaron ocho aislados de AmSR

${ }^{1}$ Manuscript submitted to Editorial Board 23 June 2011.

${ }^{2}$ Funding for this project was provided by TSTAR-CSREES award \# 2005-34135-16283.

${ }^{3}$ Graduate student, Department of Crops and Agroenvironmental Sciences, University of Puerto Rico, Mayagüez, PR.

${ }^{4}$ Associate Professor, Department of Crops and Agroenvironmental Sciences, University of Puerto Rico, Mayagüez, PR. Corresponding author: consuelo.estevez@upr.edu 
infectando Lablab purpureus en la cordillera central de Puerto Rico. Se realizó análisis molecular filogenético de la región interna transcrita (ITS), incluyendo la región $5.8 \mathrm{~S}$ ribosomal (rADN). La topología del árbol generado por los métodos de parsimonia y Neighbor-Joining fue similar. Los aislados se identificaron como Phakopsora meibomiae con un porcentaje de identidad entre el 98 y $100 \%$. Estos aislados fueron agrupados en un grupo monofilético. Phakopsora pachyrhizi fue la especie más relacionada, y formó un segundo clado. Otras especies de royas de los géneros Uromyces, Puccinia, Tranzschelia, Hemileia, el carbón Ustilago y la seta comestible Boletus se incluyeron en el análisis como grupos distantes. Las especies de Phakopsora agrupadas en la familia Pucciniaceae forman un clado hermano con las familias Phakopsoraceae y Uropyxidaceae.

Palabras clave: Roya americana de la soya, análisis filogenético

\section{INTRODUCTION}

Soybean rust is caused by two Phakopsora species, $P$. meibomiae (Arthur) Arthur named American Soybean Rust (AmSR), and $P$. pachyrhizi Sydow commonly named Asian Soybean Rust (ASR) (Frederick et al., 2002; Posada-Buitrago and Frederick, 2005; Pivonia and Yang, 2004; Villavicencio et al., 2007; Yorinori et al., 2005). Phakopsora meibomiae is endemic to Central America, South America and the Caribbean (Bonde et al., 2006; Ono et al., 1992) and was reported in wild legumes under the name of Uredo vignae Bresadola (Ono et al., 1992). Earlier studies of rust infection in legumes in the Caribbean region reported Uredo concors Arthur and Physopella concors Arthur as the causal agents of the disease (Arthur, 1915; Arthur, 1917). In the Americas, AmSR was described in 1917 in Mexico, in 1940 in Guatemala, and later in 1976 in Costa Rica infecting wild legumes (Cummins, 1943; Bromfield, 1984). Phakopsora meibomiae has been reported in 15 wild legume species of the subfamily Papilionoidea (Ono et al., 1992).

Phakopsora pachyrhizi was first recorded in Japan in 1903 (Bromfield, 1984). In the Americas it was reported for the first time in Paraguay in 2001 (Yorinori et al., 2005) and was rapidly disseminated to Argentina, Bolivia, Brazil and Colombia (Rossi, 2003; Hartman et al., 2004; Pan et al., 2006). Asian soybean rust was reported for the first time in 2004 in the continental United States in Louisiana (Schneider et al., 2005).

In 1976 an outbreak of soybean rust was observed in Adjuntas, Puerto Rico, infecting scarlet runner bean and soybean (Vakili and Bromfield, 1976). From 1976 to 1979, field surveys of endemic legumes of Puerto Rico confirmed the presence of rust infecting Lablab purpureus, Vigna luteola, Teramnus uncinatus, Phaseolus lunatus, P. vulgaris, Crotalaria pallida and Macroptilium lathyroides (Vakili, 1979; Vakili, 
1981). The pathogen was erroneously identified as $P$. pachyrhizi until Ono et al. (1992) reclassified it as $P$. meibomiae on the basis of the telial stage found in samples collected in the Americas, including samples collected by Vakili in Puerto Rico.

Both Phakopsora species infect a broad range of plant species. Even though Phakopsora species produce only the anamorph stage, they could produce telia under favorable conditions (Ono et al., 1992). Phakopsora meibomiae naturally infects 42 species of legumes in 19 genera. Under controlled conditions, 18 additional species in 12 genera are reported to be infected by this pathogen. Phakopsora pachyrhizi naturally infects 31 species of legumes in 17 genera; under controlled conditions 60 species in 26 additional genera have been infected. For both species, 24 plant species in 19 genera have been reported to be hosts (Frederick et al., 2002; Ono et al., 1992). Differences in virulence between $P$. meibomiae and P. pachyrhizi have been documented (Bonde et al., 2006).

Morphological differences between teleomorphs of the two Phakopsora species are similar with groupings based on the sequence of the internal transcribed spacer (ITS) (Frederick et al., 2002). Based on nucleotide sequences, specific primers were developed for their rapid and accurate identification using both conventional and real-time PCR (Frederick et al., 2002; Lamour et al., 2006).

Phylogenetic analyses based on DNA regions have served to define relationships among different organisms (Chatasiri and Ono, 2008). The use of the ITS region of the rDNA of the Puccinia monoica complex (Roy et al., 1998), Uromyces pisi complex (Pfunder et al., 2001), Melampsora epitea (Smith et al., 2004), Puccinia hemerocallidis (Chatasiri et al., 2006), Puccinia andropogonis and Puccinia coronata (Szabo, 2006), among others, has been successful in phylogenetic analyses of rust taxa.

The objective of this study was to identify and characterize eight isolates of AmSR collected in the central mountainous region of Puerto Rico, on the basis of the sequence of the ITS region of their rDNA.

\section{MATERIALS AND METHODS}

Selected isolates. Eight isolates of $P$. meibomiae infecting Lablab purpureus collected during 2008 were used in the present study (Table 1). All specimens were deposited in the Herbarium of the Plant Disease Clinic at the Juana Díaz Substation, University of Puerto Rico.

For ITS analyses, GenBank sequences of $P$. pachyrhizi (AF333488), Uromyces vignae (AB115736), U. appendiculatus (DQ411531), Puccinia hordei (DQ460723), P. coronata f. sp. avenae (EU014044), Hemileia 
TABLE 1.-Isolates of Phakopsora meibomiae used in the present study.

\begin{tabular}{|c|c|c|c|}
\hline Isolate No. & $\begin{array}{l}\text { Site of } \\
\text { Collection }\end{array}$ & Location & $\begin{array}{c}\text { GenBank } \\
\text { accession No. }\end{array}$ \\
\hline LP17 & Jayuya & N $18^{\circ} 11.576^{\prime} ;$ W $066^{\circ} 30.965^{\prime}$ & GQ146460 \\
\hline LP18 & Adjuntas & N $18^{\circ} 11.162^{\prime}$; W $066^{\circ} 45.411^{\prime}$ & GQ146461 \\
\hline LP19 & Barranquitas & N $18^{\circ} 11.833^{\prime} ;$ W $066^{\circ} 22.115$ & GQ146462 \\
\hline LP20 & Aibonito & N $18^{\circ} 08.205^{\circ}$; W $066^{\circ} 17.522^{\prime}$ & GQ146463 \\
\hline LP21 & Aibonito & N $18^{\circ} 07.492^{\prime}$; W $066^{\circ} 17.480^{\prime}$ & GQ146464 \\
\hline LP22 & Yahuecas & N $18^{\circ} 11.897^{\prime}$; W $066^{\circ} 47.895^{\prime}$ & GQ146465 \\
\hline LP23 & Adjuntas & N $18^{\circ} 10.474^{\prime}$ W $066^{\circ} 47.962$ & GQ146466 \\
\hline LP24 & Adjuntas & N $18^{\circ} 10.855^{\prime} ;$ W $066^{\circ} 46.123^{\prime}$ & GQ146467 \\
\hline
\end{tabular}

vastatrix (EF394132), Tranzschelia discolor (EU014071), Ustilago hordei (AY345003), and Boletus mirabilis (AF335451) were used as the outgroups (Table 2). Additionally, the sequence of $P$. meibomiae (AF333502) was used as reference.

DNA extraction, polymerase chain reaction and DNA sequencing. Total DNA was extracted from 1 to $5 \mathrm{mg}$ of urediniospores. Urediniospores were deposited in a 2-ml Eppendorf tube with three glass beads of 5-mm diameter (Fisher Scientific, Pittsburgh, PA) ${ }^{5}$. The extraction of DNA was conducted with the DNeasy Plant Mini kit (Qiagen, Valencia, CA) according to the manufacturer's instructions, increasing the incubation time from 15 to 60 minutes. The ITS region, including 5.8S rDNA, was amplified with the primers ITS1 (5'-TCCGTAGGTGAACCTGCGG-3) and ITS4 (5'-TCCTCCGCTTATTGATATGC-3') (Integrated DNA Technologies, Coralville, IA) in a total volume of $20 \mu \mathrm{l}$. The PCR reaction contained REDExtract-N-Amp PCR ready mix (Sigma-Aldrich, St. Louis, MO) with each primer at a concentration of $20 \mathrm{pmol}$, and the use of 5 to $50 \mathrm{ng}$ of extracted template DNA. Amplification of extracted DNA was performed in a thermocycler model T 3000 (Biometra, Goettingen, Germany) under the following conditions: $94^{\circ} \mathrm{C}$ for $1 \mathrm{~min}$ initial denaturation, followed by 35 cycles of $94^{\circ}$ $\mathrm{C}$ for $30 \mathrm{~s}, 55^{\circ} \mathrm{C}$ for $30 \mathrm{~s}$, and $72^{\circ} \mathrm{C}$ for $1 \mathrm{~min}$, and a final extension for 6 min at $72^{\circ} \mathrm{C}$ (White et al., 1990; Fernández, 2005). The amplification products were visualized by using a UV transluminator after electrophoresis in a $1.0 \%$ agarose gel stained with ethidium bromide. The PCR products were purified and sequenced at the Sequencing and Genotyping facility of the University of Puerto Rico in Río Piedras (http:// mec.com.pr).

\footnotetext{
${ }^{5}$ Company or trade names in this publication are used only to provide specific information. Mention of a company or trade name does not constitute a warranty of equipment or materials by the Agricultural Experiment Station of the University of Puerto Rico, nor is this mention a statement of preference over other equipment or materials.
} 
TABLE 2.-Previously characterized fungal species and GenBank sequences used in the phylogenetic analyses.

\begin{tabular}{|c|c|c|}
\hline Fungus & Source & $\begin{array}{c}\text { GenBank } \\
\text { accession No. }\end{array}$ \\
\hline Phakopsora meibomiae isolate Puerto Rico & $\begin{array}{l}\text { Frederick, R. D., Snyder, C. L., Peterson, G. L. and Bonde, } \\
\text { M. R. }\end{array}$ & AF333502 \\
\hline Phakopsora pachyrhizi isolate Australia $72-1$ & $\begin{array}{l}\text { Frederick, R. D., Snyder, C. L., Peterson, G. L. and Bonde, } \\
\text { M. R. }\end{array}$ & AF333488 \\
\hline Uromyces vignae & Chung, W. H., Tsukiboshi, T., Ono, Y. and Kakishima, M. & $\mathrm{AB} 115736$ \\
\hline Uromyces appendiculatus isolate AFTOL-ID 976 clone 2 & Matheny, P. B., Aime, M. C. and Hibbett, D. S. & DQ411531 \\
\hline Puccinia hordei-secalini isolate RN-3 & Jafary, H., Szabo, L. J. and Niks, R. E. & DQ460723 \\
\hline Puccinia coronata f. sp. avenae isolate R201 clone 01 & $\begin{array}{l}\text { Alaei, H., De Backer, M., Nuytinck, J., Maes, M., Hofte, M. } \\
\text { and Heungens, K. }\end{array}$ & EU014044 \\
\hline Hemileia vastatrix isolate CT-9-8 & Cristancho, M. A., Escobar, C., Varzea, V. and Ribeiro, A. I. & EF394132 \\
\hline Tranzschelia discolor isolate R218 clone 01 & $\begin{array}{l}\text { Alaei, H., De Backer, M., Nuytinck, J., Maes, M., Hofte, M. } \\
\text { and Heungens, K. }\end{array}$ & EU014071 \\
\hline Ustilago hordei & Stoll, M., Piepenbring, M., Begerow, D. and Oberwinkler, F. & $\mathrm{AY} 345003$ \\
\hline Boletus mirabilis & Berbee, M. L., Inderbitzin, P. and Zhang, G. & AF335451 \\
\hline
\end{tabular}


Alignment and phylogenetic analyses. DNA sequences were aligned and manually edited by using the Sequencher program, version 4.5 (Gibbs and Cockerill, 1995). Sequence data were deposited in GenBank (Table 1). Multiple alignment was performed by using the BioEdit program, version 7.0.4.1 (Hall, 1999). Phylogenetic analyses were performed by using heuristic maximum parsimony and maximum likelihood methods in MEGA, version 4.1 (Tamura et al., 2007). Node support in parsimony analyses was assessed by bootstrapping with 1,000 pseudoreplicates, each with 10 random additions of the included taxa to increase the likelihood of finding the most parsimonious tree. Evolutionary distances for the aligned sequences were computed by using the maximum composite likelihood method and were analyzed by the Neighbor-Joining method. The relative nodal support was calculated by using bootstrapping with 1,000 psuedoreplicates. All positions containing gaps and missing data were eliminated from the analysis.

\section{RESULTS AND DISCUSSION}

The partial sequence of both the 18S rRNA gene and the ITS2 region, as well as the complete sequence of the 5.8S rRNA gene and the ITS1 region of the eight isolates, corresponded to $P$. meibomiae with an identity ranging from 98 to $100 \%$. The length of the ITS1 ranged from 214 to $218 \mathrm{bp}$, whereas the length of the $5.8 \mathrm{~S}$ ranged from 152 to $154 \mathrm{bp}$. The coverage of the sequenced region varied from 81 to $100 \%$. The gaps found varied from one to seven base pairs (bp). The length of the sequenced region (partial sequence of both 18S and ITS2; and complete sequence of both $5.8 \mathrm{~S}$ and ITS1) ranged from 466 to $552 \mathrm{bp}$ (Table 3). Both the ITS region and the intergenic spacer of the nuclear rRNA genes have been used as powerful tools to characterize phyloge-

TABLE 3.-Identification and molecular characterization of isolates used in the present study.

\begin{tabular}{llcccc}
\hline Isolate No. & BLAST identification & \% Identity & \% & Coverage & \\
LP17 & Phakopsora meibomiae & 99 & 87 & $2 / 463$ & 526 \\
LP18 & P. meibomiae & 100 & 99 & $4 / 463$ & 492 \\
LP19 & P. meibomiae & 99 & 83 & $1 / 462$ & 552 \\
LP20 & P. meibomiae & 99 & 82 & $3 / 435$ & 525 \\
LP21 & P. meibomiae & 99 & 86 & $4 / 405$ & 466 \\
LP22 & P. meibomiae & 99 & 100 & $3 / 443$ & 543 \\
LP23 & P. meibomiae & 98 & 86 & $7 / 430$ & 491 \\
LP24 & P. meibomiae & 98 & 81 & $6 / 447$ & 543 \\
\hline
\end{tabular}

\footnotetext{
${ }^{1}$ Based on BLAST analyses.

${ }^{2}$ Length (bp) of $18 \mathrm{~S}$ rDNA partial sequence, ITS1 and 5.8S rDNA complete sequence and ITS2 partial sequence.
} 
netically different taxonomic groups (White et al., 1990). Furthermore, ribosomal genes present a high number of copies within a single genome, possess variable and conserved regions, and can be amplified and sequenced with universal primers (Henson and French, 1993). Therefore, the ITS region has been used in phylogeny and taxonomy of closely related species such as the Asian grapevine leaf rust, caused by Phakopsora euvitis (Chatasiri and Ono, 2008).

Problems associated with DNA extraction and ITS sequencing produced the variation in the number of bp sequenced among the isolates, and these problems have frequently been found during sequencing of the ITS region of biotrophs, such as soybean rust. Chatasari and Ono (2008) found differences in 20 base positions in the ITS2 sequence of $P$. euvitis between the Japanese and the Australian-East Timor isolates. Nevertheless, one Japanese isolate, compared with 18 isolates of the same country, showed one bp difference in the ITS2 region at positions 170 and 367 (Chatasiri and Ono, 2008).

Of the 1,437 aligned characters, 442 were conserved, 946 were variable, and 355 were parsimony informative. The maximum parsimony method generated 113 trees with a tree length of 564 steps, a retention index of 0.701 , and a composite index of 0.4885 (Figure 1). The

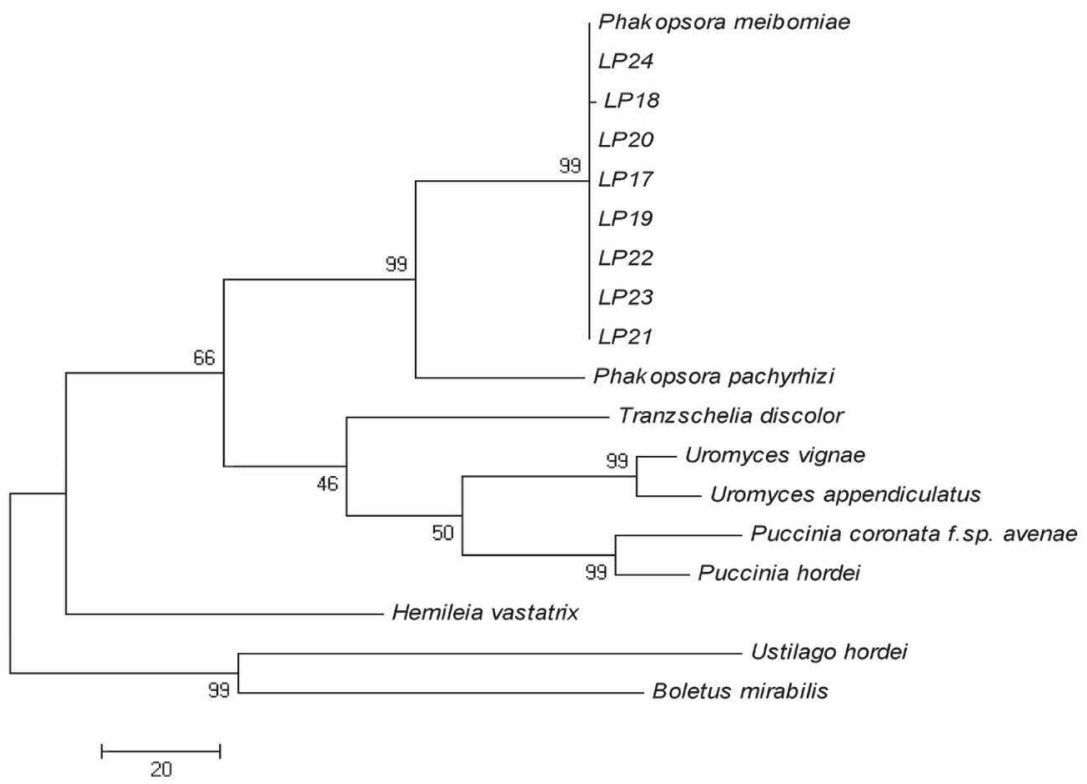

Figure 1. Consensus parsimony tree constructed from sequences of the ITS1-5.8SITS2 region, fungal species names and isolate numbers are shown in the figure; the bootstrap values calculated from 1,000 replicates are given above and below the branches. 
Neighbor-Joining (NJ) tree obtained by the distance method showed a topology identical to the consensus parsimony tree. The sum of the optimal tree branch length was 2.4569 (Figure 2).

Together, eight $P$. meibomiae Puerto Rico isolates formed a sister clade with a boostrap value of 100 . Phakopsora pachyrhizi was the most closely related species, forming a second clade. Both species belong to the Phakopsoraceae family. According to Frederick et al. (2002), the comparison of the ITS1 regions of $P$. pachyrhizi and P. meibomiae showed 49 nucleotide differences, equivalent to $77.5 \%$ identity between the two species. The comparison of the ITS2 regions showed 64 nucleotide differences, representing $68.5 \%$ identity between the two Phakopsora species. Thus, this molecular differentiation supports the biological and taxonomic distinctness of the two Phakopsora species (Ono et al., 1992).

The species grouped in the Pucciniaceae family, Uromyces vignae and $U$. appendiculatus, as well as the species Puccinia coronate f. sp. avenae and $P$. hordei, formed a sister clade between each group, with a bootstrap value of 100 . Nevertheless, Tranzschelia discolor showed a closer evolutionary relationship with $U$. vignae, $U$. appendiculatus, $P$. coronata f. sp. avenae, and with $P$. hordei than with $P$. meibomiae and $P$.

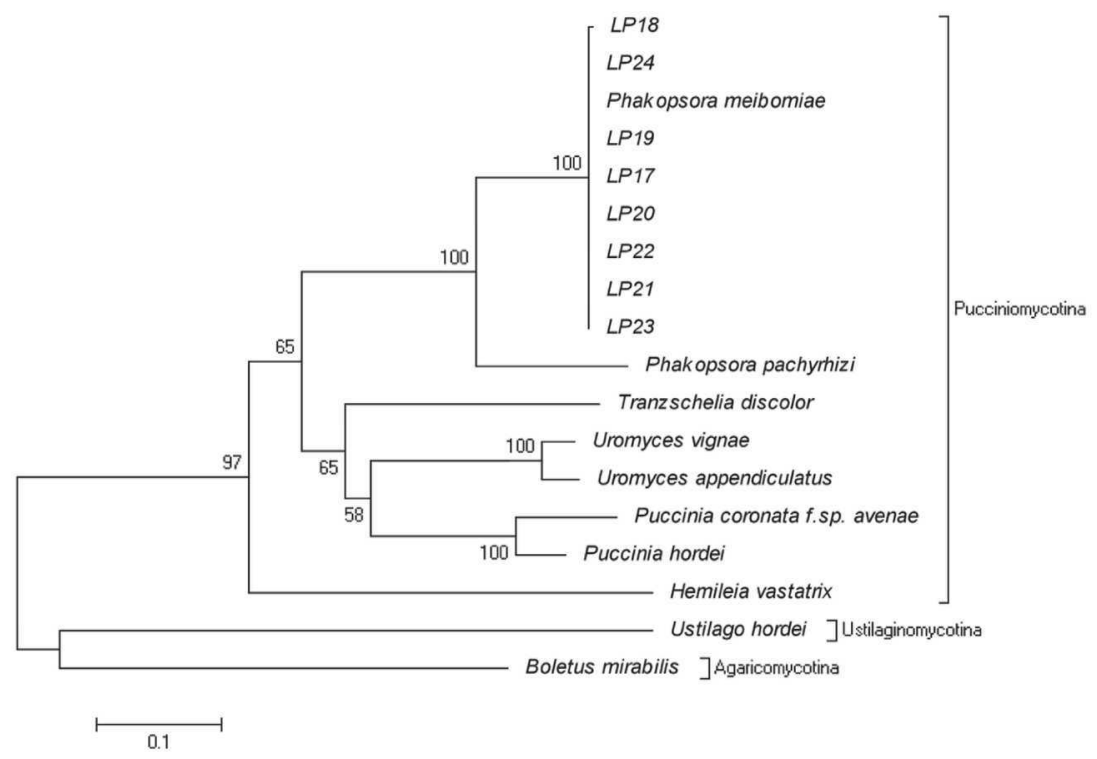

Figure 2. A Neighbor-Joining tree constructed from sequences of the ITS1-5.8SITS2 region, fungal species names and isolate numbers are shown in the figure; the bootstrap values calculated from 1,000 replicates are given above and below the branches. 
pachyrhizi. Even though Hemileia vastatrix belongs to Pucciniomycotina subphylum, it showed a tight evolutionary relationship with species of the families Phakopsoraceae, Pucciniaceae, and Uropyxidaceae (T. discolor). Furthermore, Ustilago hordei (Subphylum: Ustilaginomycotina) and Boletus mirabilis (Subphylum: Agaricomycotina) showed a closer relationship than species belonging to the Pucciniomycotina subphylum (Cummins and Hiratsuka, 2004; Hibbett et al., 2007).

In summary, the findings presented here showed that the isolates collected on L. purpureus in the central mountain region of Puerto Rico correspond to P. meibomiae. Extensive surveys for genetic variation of $P$. meibomiae infecting wild legumes are needed to identify the possible source of Puerto Rican populations.

\section{LITERATURE CITED}

Arthur, J. C., 1915. Uredinales of Porto Rico based on collections by F. L. Stevens. $M y$ cologia $7:$ 315-332.

Arthur, J. C., 1917. Uredinales of Porto Rico based on collections by H. H. Whetzel and E. W. Olive. Mycologia 9: 55-104.

Bonde, M. R., S. E. Nester, C. N. Austin, C. L. Stone and R. D. Frederick, 2006. Evaluation of virulence of Phakopsora pachyrhizi and P. meibomiae isolates. Plant Dis. 90: 709-716.

Bromfield, K. R., 1984. Soybean rust, Monograph No. 11. The American Phytopathological Society, St. Paul, Minnesota. $57 \mathrm{pp}$.

Chatasiri, S., O. Kitade and Y. Ono, 2006. Phylogenetic relationships among Puccinia hemerocallidis, $P$. funkiae, and P. patriniae (Uredinales). Mycoscience 47: 123-129.

Chatasiri, S. and Y. Ono, 2008. Phylogeny and taxonomy of the Asian grapevine leaf rust fungus, Phakopsora euvitis, and its allies (Uredinales). Mycoscience 49: 66-74.

Cummins, G. B., 1943. Description of tropical rusts-V. Bull. Torrey Bot. Club 70:68-81.

Cummins, G. B. and Y. Hiratsuka, 2004. Illustrated genera of rust fungi. Third edition. American Phytopathological Society, St. Paul, Minnesota, 240 pp.

Fernández, J., 2005. Incidencia y caracterización: morfológica, patogénica y genética de Alternaria spp. en cultivos de cebolla del sur de Puerto Rico. Tesis M.S. Universidad de Puerto Rico, Mayagüez, P.R., 167 pp.

Frederick, R. D., C. L. Synder, G. L. Peterson and M. R. Bonde, 2002. Polymerase chain reaction assays for the detection and discrimination of the soybean rust pathogens Phakopsora pachyrhizi and P. meibomiae. Phytopathology 92: 217-227.

Gibbs, R. A. and M. Cockerill, 1995. Sequencher, version 3.0. Ann Arbor: Gene Codes Corporation.

Hartman G. L., M. R. Miles and R. D. Frederick, 2004. Epidemiology and spread of soybean rust. American Seed Trade Association Conference Proceedings 1-9.

Hall, T. A., 1999. BioEdit: a user-friendly biological sequence alignment and analysis program for Windows 95/98/NT. Nucleic Acids Symposium Series 41: 95-98.

Henson, J. M. and R. French, 1993. The polymerase chain reaction and plant disease diagnosis. Annu. Rev. Phytopathol. 31: 81-109.

Hibbett, D. S., M. Binder, J. F. Bischoff, M. Blackwell, P. F. Cannon, O. E. Eriksson, S. Huhndorf, T. James, P. M. Kirk, R. Lucking, H. Thorstein Lumbsch, F. Lutzoni, P. B. Matheny, D. J. Mclaughlin, M. J. Powell, S. Redhead, C. L. Schoch, J. W. Spata- 
fora, J. A. Stalpers, R. Vilgalys, M. C. Aime, A. Aptroot, R. Bauer, D. Begerow, G. L. Benny, L. A. Castlebury, P. W. Crous, Y. Dai, W. Gams, D. M. Geiser, G. W. Griffith, C. Gueidan, D. L. Hawksworth, G. Hestmark, K. Hosaka, R. A. Humber, K. D. Hyde, J. E. Ironside, U. Koljalg, C. P. Kurtzman, K. Larsson, R. Lichtwardt, J. Longcore, J. Miadlikowska, A. Miller, J. Moncalmo, S. Mozley-Standridge, F. Oberwinkler, E. Parmasto, V. Reeb, J. D. Rogers, C. Roux, L. Ryvarden, J. P. Sampaio, A. Schübler, J. Sugiyama, R. G. Thorn, L. Tibell, W. A. Untereiner, C. Walker, Z. Wang, A. Weir, M. Weiss, M. M. White, K. Winka, Y. Yao and N. Zhang, 2007. A higher-level phylogenetic classification of the fungi. Mycol. Res. 111: 509-547.

Lamour, K., L. Finley, K. Snover, J. Stack, R. Hammerschmidt, J. Jacobs, J. Byrne, P. Harmon, A. Vitoreli, G. Wisler, C. Harmon, L. Levy, K. Zeller, C. Stone, D. Luster and R. Frederick, 2006. Early detection of Asian soybean rust using PCR. Online. Plant Health Progress doi: 10.1094/PHP-2006-0524-01-RS.

Ono, Y., P. Buriticá and J. F. Hennen, 1992. Delimitation of Phakopsora, Physopella and Cerotelium and their species on leguminosae. Mycol. Res. 96: 825-850.

Pan, Z., X. B. Yang, S. Pivonia, L. Xue and R. Pasken, 2006. Long-term prediction of soybean rust entry into the continental United States. Plant Dis. 90:840-846.

Pfunder, M., S. Schürch and B.A. Roy, 2001. Sequence variation and geographic distribution of pseudoflower-forming rust fungi (Uromyces pisi s. lat.) on Euphorbia cyparissias. Mycol. Res. 105: 57-66.

Pivonia, S. and X. B. Yang, 2004. Assessment of the potential year-round establishment of soybean rust throughout the world. Plant Dis. 88:523-529.

Posada-Buitrago, M. L. and R. D. Frederick, 2005. Expressed sequence tag analysis of the soybean rust pathogen Phakopsora pachyrhizi. Fungal Genetics and Biology 42: 949-962.

Rossi, R. L., 2003. First Report of Phakopsora pachyrhizi, the causal organism of soybean rust in the province of Misiones, Argentina. Plant Dis. 87: 102.

Roy, B. A., D. R. Vogler, T. D. Bruns and T. M. Szaro, 1998. Cryptic species in the Puccinia monoica complex. Mycologia 90: 846-853.

Schneider, R. W., C. A. Hollier, H. K. Whitam, M. E. Palm, J. M. McKemy, J. R. Hernandez, L. Levy and R. DeVries-Paterson, 2005. First report of soybean rust caused by Phakopsora pachyrhizi in the continental United States. Plant Dis. 89: 774.

Smith, J. A., R.A. Blanchett and G. Newcombe, 2004. Molecular and morphological characterization of the willow rust fungus, Melampsora epitea, from arctic and temperate hosts in North America. Mycologia 96: 1330-1338.

Szabo, L. J., 2006. Deciphering species complexes: Puccinia andropogonis and Puccinia coronata, examples of differing mode of speciation. Mycoscience 47: 130-136.

Tamura, K., J. Dudley, M. Nei and S. Kumar, 2007. MEGA4: Molecular Evolutionary Genetics Analysis (MEGA) software version 4.0. Molecular Biology and Evolution 24: 1596-1599.

Vakili, N. G., 1981. Distribution of Phakopsora pachyrhizi on Lablab purpureus in Puerto Rico. Plant Dis. 65: 817-819.

Vakili, N. G., 1979. Field survey of endemic leguminous hosts of Phakopsora pachyrhizi in Puerto Rico. Plant Dis. Rep. 63: 931-935.

Vakili, N. G. and K. R. Bromfield, 1976. Phakopsora rust on soybean and other legumes in Puerto Rico. Plant Dis. Rep. 60: 995-999.

Villavicencio, A. L., G. B. Fanaro, M. M. Araújo, S. Aquino, P. V. Silva and J. Mancini Filho, 2007. Detection of Phakopsora pachyrhizi by polymerase chain reaction (PCR) and use of germination test and DNA comet assay after e-beam processing in soybean. Radiation Physics and Chemistry 76: 1878-1881.

White, T. J., T. Bruns, S. Lee and J. Taylor, 1990. Amplification and direct sequencing of 
fungal ribosomal RNA genes for phylogenetics. In: M. Innis, D. Gelfand, J. Sninsky and T. White (ed.). PCR Protocols a guide to methods and applications, pp. 315-322. Academic Press, San Diego, California.

Yorinori, J. T., W. M. Paiva, R. D. Frederick, L. M. Costamilan, P. F. Bertagnolli, G. E. Hartman, C. V. Godoy and J. Nunes, 2005. Epidemics of soybean rust (Phakopsora pachyrhizi) in Brazil and Paraguay from 2001 to 2003. Plant Dis. 89: 675-677. 
